\title{
Working
}

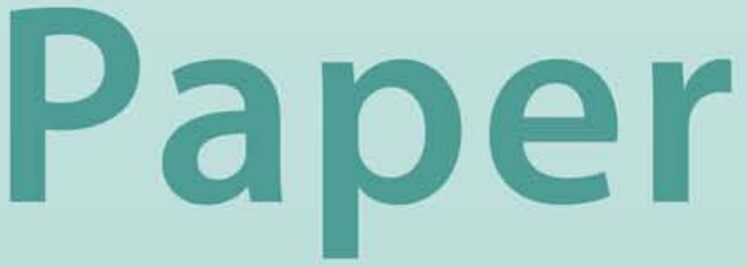




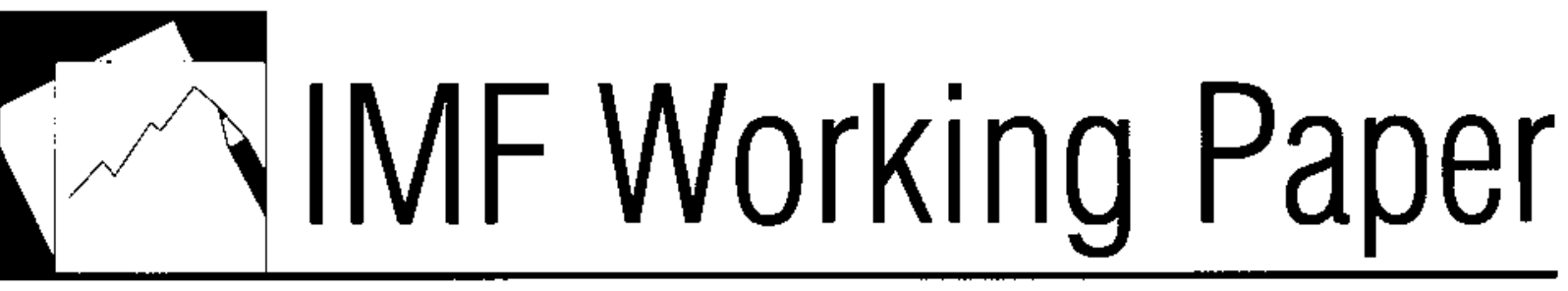

Spatial Spillovers in Emerging Market Spreads

Emanuele Baldacci, Salvatore Dell'Erba, Tigran Poghosyan 


\title{
IMF Working Paper
}

Fiscal Affairs Department

\section{Spatial Spillovers in Emerging Market Spreads}

\author{
Prepared by Emanuele Baldacci, Salvatore Dell’Erba, Tigran Poghosyan ${ }^{1}$
}

Authorized for distribution by Abdelhak Senhadji

September 2011

\begin{abstract}
This Working Paper should not be reported as representing the views of the IMF. The views expressed in this Working Paper are those of the author(s) and do not necessarily represent those of the IMF or IMF policy. Working Papers describe research in progress by the author(s) and are published to elicit comments and to further debate.

We use novel spatial econometrics techniques to explore spillovers in the sovereign bond market for 24 emerging economies during 1995-2010. The paper extends the previous literature focusing on spillover effects from advanced to emerging economies by analyzing transmission of shocks across emerging markets. After controlling for the impact of global factors, we find strong evidence of spillovers from both sovereign spreads and macroeconomic fundamentals in neighboring emerging economies. In addition to the geographical proximity, the channels of spatial transmission include trade and financial linkages. The results of the paper highlight the importance of accounting not only for spillovers from advanced economies to emerging markets, but also across emerging markets when analyzing sovereign spreads.
\end{abstract}

JEL Classification Numbers: $\quad$ C23, F30, F32

Keywords: $\quad$ sovereign spreads, emerging market, spillovers, spatial econometrics

Author’s E-Mail Address: $\quad$ baldacci@istat.it, salvatore.dellerba@graduateinstitute.ch, tpoghosyan@imf.org.

\footnotetext{
${ }^{1}$ The authors would like to thank Tamim Bayoumi, Stijn Claessens, Lorenzo Forni, Philip Liu, Abdelhak Senhadji, Hui Tong, as well as seminar participants at the IMF for useful comments on an earlier version of the paper. Oriel Fernandes and Malin Hu provided excellent research assistance.
} 


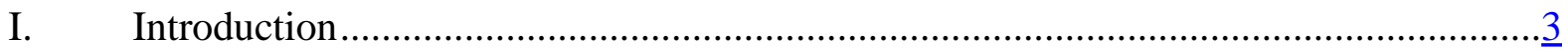

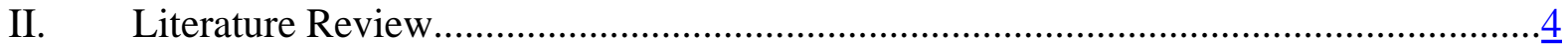

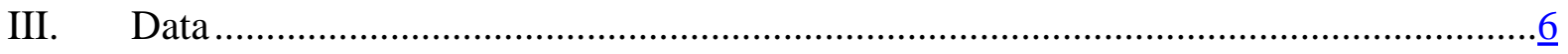

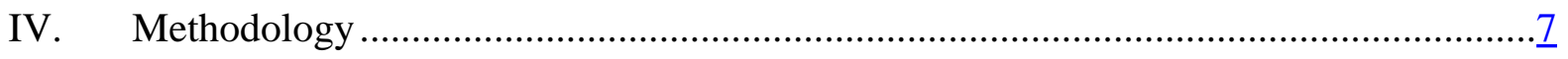

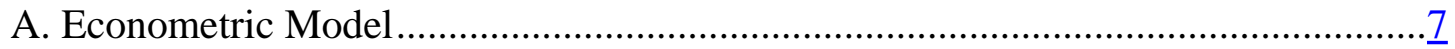

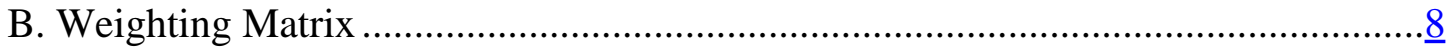

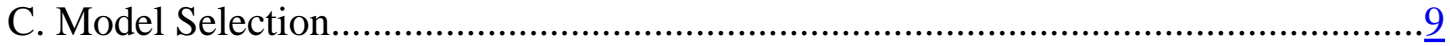

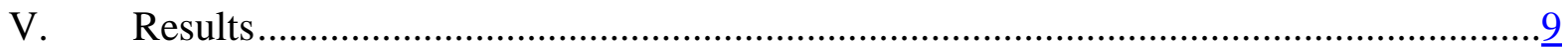

A. Different Weighting Matrices ...................................................................12

VI. Robustness and Extensions .......................................................................... 14

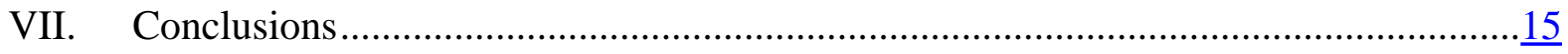

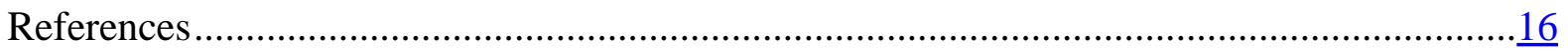

Figures

1. Sovereign Spreads in Emerging Markets (in basis points) ......................................19

2. SAR: The Impact of a 1 ppt Increase in External Debt to GDP Ratio.........................20

3. SDM: The Impact of a 1 ppt Increase in External Debt to GDP Ratio........................21

Tables

1. Description of Variables and their Sources ........................................................22

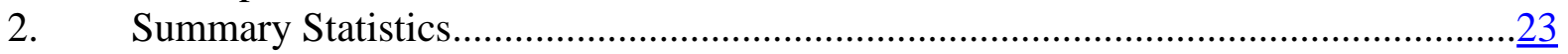

3. Tests of Cross Sectional Dependence ..............................................................24

4. $\quad$ Estimation Results: Fixed-Effects, Spatial Error, and Spatial Lag Models .................25

5. Decomposition of the Total Impact into Direct and Indirect Effects.........................26

6. Estimation Results: Spatial Lag Model with Alternative Weighting Matrices.............27

7. Robustness Checks........................................................................................ 28 


\section{INTRODUCTION}

After the Lehman collapse, the transmission of the crisis from advanced economies (AE) to emerging market economies (EM) initially produced financial stress comparable to the levels observed in the 90s crises (Balakrishnan et al. 2009). As shown in Figure 1, the average sovereign spread of emerging countries included in the EMBI Global Diversified index, reached the peak of 1,000 bps in the Fall of 2008, which is comparable to the peak observed during the Mexican and Russian crises of the 1980s and 1990s. The negative impact was short-lived though and after a year spreads returned to their pre-crisis levels. Two main events stood parallel to this process. First, the pace of the economic recovery in EM was fast, and particularly so for countries less exposed to AE. Second, as the crisis intensified in AE, stronger macroeconomic fundamentals in EM generated a resurgence of interest from investors, ensuring a resumption of capital inflows to these countries.

In light of this evidence, the objective of this paper is to reassess the determinants of sovereign risk in EM by focusing on intra-EM spillovers. Specifically, we are interested in analyzing whether the strengthened trade and financial linkages between EM observed in the past years (IMF 2011a, 2011b) can explain the evolution of sovereign risks in this group of countries, measured by the difference between the yield on a country's sovereign debt and the U.S. 10-year treasury note. We ask the following questions: do geographical proximity and economic linkages matter in the transmission of fundamental risks between EM? How important are these intra-EM spillovers relative to spillovers from AE to EM?

To address these questions, the paper uses novel spatial regression methods. Following a now established practice in the analysis of determinants of sovereign yields and spreads, we measure fundamentals by using forward looking indicators, rather than actual data. ${ }^{2}$ For this reason, we construct a "real-time" dataset of fiscal and macroeconomic variables for a panel of 24 EM covering the period 1995-2010. ${ }^{3}$ We augment this database with information on global factors and economic links across countries, such as geographic proximity, bilateral trade and financial exposure. Since financial variables like sovereign spreads show a high

\footnotetext{
${ }^{2}$ Among papers that use real-time data: Laubach (2009) analyzes the impact of fiscal policy on long term U.S. yields; Dell'Erba and Sola (2011) analyze the determinants of sovereign yields in OECD countries; Alper and Forni (2011) assess debt spillover in advanced and emerging economies; Sgherri and Zoli (2009) analyze determinants of spreads in the euro area.

${ }^{3}$ Throughout the text, we will use the term "real-time" to refer to the forecast values of variables from different WEO vintages, as opposed to early releases of macro data that are subject to statistical revision. Contrary to actual data, "real-time" data can be considered a proxy for investors' expectations. Under the assumption that asset prices incorporate news rapidly, the real time variable is expected to affect the sovereign spreads via the information content it provides. Since the sovereign spreads are sampled after the release of the forecast, one can expect that their value incorporates this information, without the fundamentals being affected by the spreads. Our estimations show that regressions based on "real-time" values of determinants offer better fit than regressions based on actual values, supporting the above reasoning.
} 
level of co-movement, it is likely that development of sovereign spreads in one emerging country are affected by developments in sovereign spreads and fundamentals in other emerging countries depending on the degree of interconnectedness. This non-zero correlation across units of observation is called cross-sectional dependence (CSD). Standard panel estimators are biased and inconsistent in the presence of CSD, while spatial econometrics techniques are robust.

We find three key results. First, EM fundamentals explain a large share of the movement in spreads (46 percent), but global factors (such as global risk aversion and liquidity) still explain more than half of the spread dynamics. Second, intra-EM spillovers are important and strengthened over time. Once we account for contemporaneous feedbacks from neighboring countries, the explanatory power of domestic factors, especially growth rates, increases substantially. Third, trade linkages are stronger transmission channels than financial linkages.

The paper is structured as follows. Section II provides a brief review of the literature, followed by data description in Section III. Section IV presents the spatial model used in our estimations. Section V discusses main results, while Section VI analyzes the key transmission channels. Section VI presents some robustness checks and extensions. Section VIII concludes and outlines avenues for future research.

\section{LITERATURE REVIEW}

Since the seminal paper by Edwards (1984), many authors have documented the importance of economic fundamentals as determinants of sovereign risk. These studies have generally used low-frequency data, available at either annual or quarterly frequency depending on the macroeconomic variable of interest, and found significant impact on the spreads of indicators of external vulnerability like external debt, debt service or current account (Edwards, 1984); fiscal variables, like fiscal debt and deficits (Baldacci and Kumar, 2010) or their composition (Akitobi and Stratmann, 2008); other variables like inflation, terms of trade and real exchange rate (Min, 1998). ${ }^{4}$

Another strand of literature has focused on global factors as determinants of sovereign risk mainly using high frequency (daily or weekly) data. McGuire and Schrijvers (2003) analyze common factors in the movements of spreads, and show that one single factor, highly correlated with the measure of investors' risk tolerance, explains a large share of the spreads' movements. Uribe and Yue (2006) show the importance of global liquidity in the transmission of shocks to EM, while Bellas et al. (2010) highlight the role of financial

\footnotetext{
${ }^{4}$ Several studies have also looked at sovereign countries' debt ratings as a proxy for sovereign risk. The evidence suggests that rating changes are often anticipated by the markets, thus leaving open an issue of reverse causality (Gonzales Rosada and Levy-Yeyati, 2008).
} 
distress in advanced economies. Gonzales-Rosada and Levy-Yeyati (2008) look instead at the impact of a broader set of global factors, which include global risk, global liquidity, and crises in other countries.

On the extent of crisis spillovers and transmission, the literature has intensively studied the causes behind the increased cross-country correlation of asset prices during crisis times, a phenomenon known as “contagion” (Dornbusch et al, 2000). While there is still a debate on how to properly distinguish "contagion" from "interdependence" in the data (Forbes and Rigobon, 2000; Pesaran and Pick, 2007), the literature has investigated the economic linkages behind regional transmission of shocks (Kaminsky and Reinhart, 2000). While trade linkages matter more than macroeconomic similarities (Eichengreen et al, 1996; Glick and Rose, 1999), financial linkages, as measured by exposure to a common lender, also seem to exert an effect on cross country correlation (Sbracia and Zaghini, 2000; Caramazza et al. 2000; Van Rijckeghem and Weder, 2000). ${ }^{5}$ Claessens et al. (2011) analyze transmission of the global financial crisis on individual firm performance using the share of foreign assets and liabilities over GDP as a proxy for global financial linkages. Acharya et al. (2011) argue on both theoretical and empirical ground that financial sector bailouts may affect sovereign spreads.

In this paper, we combine the above mentioned approaches and analyze the impact of fundamentals on spreads, controlling for global factors and macroeconomic linkages. We sidestep the issue of contagion (i.e., temporary overreaction of sovereign spread changes in response to economic shocks), which is typically captured in high frequency data. Instead, we focus on the issue of spillovers by using low frequency data, in which temporary fluctuations are smoothed out and remaining spatial dependence can be attributed to crosscountry linkages. To take into account cross-country linkages we use spatial econometrics techniques, which allow for contemporaneous feedbacks arising from countries' interdependence. There are a few papers studying the issue of contagion from a spatial econometrics perspective, but their focus is on the analysis of currency crises (Hondroyiannis et al. 2006; Novo, 2003). Our paper is similar in spirit to Hernandez and Valdes (2001), although contrary to them, we do not analyze contagion and we use a different estimation strategy. The authors analyze whether geographic proximity, competition for funds or trade explain contagion in sovereign spreads during the Thai, Russian and Brazilian crises of the end of the 90s. Our focus is on the issue of spillovers from fundamentals to sovereign risk through real linkages.

\footnotetext{
${ }^{5}$ Common lender refers to the circumstance in which several countries depend financially on the same creditor, normally banks in a given country.
} 


\section{DATA}

Our dependent variable is the secondary market stripped yield on sovereign spreads from J.P. Morgan's EMBI Global (EMBIG), i.e., the difference between the weighted average yield to maturity of a country's bonds which are included in the index ${ }^{6}$, minus the yield of a U.S. treasury bond of similar maturity. The EMBIG is composed of U.S. dollar denominated sovereign or quasi-sovereign denominated Brady Bonds, Eurobonds and loans. Stripped bond spreads data are available since 1994, but the starting point differs across countries. The reasons why we adopt this measure are threefold: (i) the EMBIG has been widely analyzed in the academic literature and its analysis allows us to compare our results with previous work; (ii) secondary spreads tend to predict actual borrowing costs as shown by Eichengreen and Mody (2000); (iii) sovereign spreads determine borrowing costs in EM as shown by Durbin and $\mathrm{Ng}$ (2005); ${ }^{7}$ understanding their determinants is thus of importance to policymakers.

There is a consensus in the literature on the impact of common factors on sovereign spreads. We thus introduce in the analysis two proxies, one for global liquidity and one for global risk aversion. To proxy for global liquidity, we use the implied yield on the three-month Fed Funds futures. This variable contains market expectations of future short-term rates in the U.S., which is likely to affect directly the borrowing costs in EM which are denominated in dollars. As a proxy for global risk, we use the Chicago Board Options Exchange Volatility Index (VIX), which is a measure of investors' attitude toward risk. As shown by McGuire and Schrijvers (2003), this variable is highly correlated with the first principal component extracted from the series of the spreads.

We construct a real-time dataset of domestic factors using different vintages of the World Economic Outlook (WEO). The WEO releases two editions per year, typically in April and October, both of which contain projections on a number of macroeconomic variables up to five years ahead. Since projections beyond a one-year horizon are of poor quality, we use only the one year ahead projection. The variables we chose to include in the estimations are standard controls that in the literature have been found to significantly affect borrowing costs in EM: total external debt to GDP; external reserves to GDP; inflation and real growth. ${ }^{8}$ The

\footnotetext{
${ }^{6}$ To be included in the EMBIG index, countries have to satisfy one of the following criteria: (i) be classified as low or middle per capita income by the World Bank; (ii) have restructured external or local debt in the past 10 years; (iii) have restructured external or local debt outstanding. For a given bond to be included in the instrument, they have to have a face value of over US\$500 million, with maturity of more than two years and six months), and verifiable daily prices and cash flows.

${ }^{7}$ On a similar point, see Cruces and Trebesch (2011). Also, the EMBI spreads are more directly comparable across countries than current yields, thus they are a more homogeneous measure of risk compared to current yields.

${ }^{8}$ Tong and Wei (2011) use domestic financial development as an additional determinant. We did not use this variable since it is not available in the real time format.
} 
use of total external debt deserves some comment. In principle, sovereign borrowing costs should be affected by the amount of total public external debt, not including private debt. Our choice to include total external debt is due to the following two reasons: as forcefully shown by the latest crisis, private and public debt become indistinguishable from an investors' perspective under deteriorating macroeconomic conditions; the WEO does not contain forecasts of the total public external debt. Therefore, one can conclude that total external debt is likely to be a good proxy for the probability of sovereign default. ${ }^{9}$ External reserves to GDP ratio are likely to directly impact spreads as they represent the ability to service external debt. Inflation is a measure of macroeconomic stability, while growth captures the business cycle. All variables are stationary by construction, since they are either ratios or growth rates. Formal unit root tests ${ }^{10}$ that account for CSD reject the null of non-stationarity in all series.

\section{Methodology}

\section{A. Econometric Model}

The aim of this section is to introduce the econometric model used for the estimation. There are several possible specifications that could be adopted to control for spatial dependence in the data. Our main specification is the Spatial Autoregressive model (SAR), which is also known as "spatial lag” model. The SAR model is given by:

$$
y_{i t}=\alpha_{i}+\gamma f_{t}+\beta x_{i t}+\rho \sum_{j=1}^{N} w_{i j} y_{j t}+\varepsilon_{i t}
$$

where $y_{i t}$ is the (log of) EMBI spread for country $i \quad(i=1, \ldots, N)$ at time $t(t=1, \ldots, T) ; \alpha_{i}$ are country specific fixed effects while $f_{t}$ represent global factors that affect all countries simultaneously; $x_{i t}$ is a matrix of control variables and $\varepsilon_{i t}$ is an i.i.d. process. The "spatial" lag correspond to the variable $\sum_{j=1}^{N} w_{i j} y_{j t}$. The latter is the sum of the dependent variable in all other countries $j$, weighted by the elements $w_{i j}$, which represent the degree of connectedness between countries $i$ and $j$. The coefficient $\rho$ is the spatial autocorrelation coefficient and it captures the feedback effect that arises from the level of the EMBI spread in neighboring countries.

\footnotetext{
${ }^{9}$ Studies that include Total External Debt to GDP are for example, Bellas et al. (2010), Akitobi and Stratmann (2008). In a separate set of regressions, we replaced the real time external debt ratio with actual total debt ratio, for which real time data was not available. The results remain qualitatively unchanged when using the total debt ratio.

${ }^{10}$ We apply the Pesaran's test that augments the standard Im, Pesaran, Shin (2003) test with cross-sectional average of all series to correct for CSD. Under the null, all series are non-stationary.
} 
The main intuition of this model is that the EMBI spread for country $i$ is directly affected by the values of EMBI spread in neighboring countries. The alternative model to the SAR assumes that the spatial correlation comes only through the error term. That is, the units of observation are cross-correlated only through shocks in neighboring units. This is the so called Spatial Error Model (SEM) which can be written in the form:

$$
y_{i t}=\alpha_{i}+\gamma f_{t}+\beta x_{i t}+\lambda \sum_{j=1}^{N} w_{i j} \varepsilon_{j t}+\varepsilon_{i t}
$$

While the SEM model only corrects for the efficiency of the estimated coefficients, the SAR model also allows for indirect, or "spillover" effects from neighboring units. Specifically, in the SAR model, the fundamentals in neighboring country $j$ indirectly affect the EMBI spread in country $i$ through their impact on the spread of country $j$ which then affects directly the dependent variable due to the existence of the spatial $\operatorname{lag}^{11}$. The existence of a feedback effect creates the simultaneity problem. Thus, the OLS estimation of the SAR is biased and the estimation has to be performed by either Maximum Likelihood (ML) or Instrumental Variable (IV) methods. In our case, we use ML, following the methodology outlined in Elhorst (2011).

\section{B. Weighting Matrix}

One crucial issue in the spatial econometric literature concerns the shape of the weighting matrix, which determines the structure of dependence among observations. The interlinkages and the connectivity across countries are specified a priori cannot be estimated through SAR. In the literature, most of the work has been done assuming geographic measures as shaping the degree of interaction across countries. In what follows, we adopt this reasoning and assume stronger interaction across EM that are more closely located geographically. Specifically, we use the inverse of the distance between capitals when defining weights $w_{i j}$.

One justification for the existence of geographic linkages among spreads can be associated to the decisions of investors seeking geographic diversification in their portfolio, thus generating cross-country correlation at the level of the spreads. However, to check for the robustness of our results, we also try different weighting matrices based on economic distances (the source of data and summary statistics are presented in Tables 1 and 2):

\footnotetext{
${ }^{11}$ Another class of model allows also the covariates in country $j$ to directly affect the dependent variable in country $i$. This model is called Spatial Durbin model (SDM) and consist in adding to the set or regressors the spatially lagged covariates $\sum_{j=1}^{N} w_{i j} x_{j t}$. LeSage and Pace (2009) show that the SDM is robust to omitted variables bias. In one of our robustness check we will also perform an estimation of the SDM.
} 
- $\quad$ trade flows, defined as the sum of bilateral export and import over GDP;

- $\quad$ financial flows, defined as the bilateral share of portfolio investment;

- $\quad$ credit rating status. We assume that two countries are linked if they share the same investment status, either above or below investment grade;

- business cycle synchronization, defined as the correlation matrix of output gaps.

\section{Model Selection}

The model selection is performed in the following steps. First, preliminary tests of crosssectional dependence (Moran's I test and the Pesaran's test) ${ }^{12}$ are performed on the dependent and independent variables and on the residual of an OLS estimation of the spreads on covariates. If they both reject the null of cross-sectional independence, we apply the robust Lagrange Multiplier (LM) test developed by Debarsy and Arthur (2010) to check the validity of the SEM model versus the SAR model ${ }^{13}$. Finally, we also perform a likelihood ratio (LR) test for the SEM versus SAR.

\section{Results}

As described in the methodology section, our preliminary analysis consists in running tests to detect CSD in the data. We first calculate the Moran's I and the Pesaran's statistics, on the dependent variable and its covariates. We then calculate the same statistics on the residual obtained from regressing the EMBI spreads on the predictors by a standard OLS estimation. The results are presented in Table 3. Both tests strongly reject the null hypothesis of crosssectional independence at conventional significance level. Therefore, we conclude that the variables show a strong degree of CSD.

Table 4 reports the comparison between estimators. The FE model is in Column 1, the SEM model is in Column 2 and the SAR model is in Column 3. The results in Column 1 broadly confirm findings of the existing literature, since all predictors are significant and correctly signed, except for inflation which is insignificant. However, this model proves inconsistent and biased under CSD. Therefore, we proceed with our specification strategy and run LM tests for a spatially lagged dependent variable or a spatially lagged error. All the tests provide evidence in favor of the SAR model. In particular, the robust LM test cannot reject the null of no spatial error, while the robust LM test for no spatial lag rejects the null at 1 percent

\footnotetext{
${ }^{12}$ Both tests calculate the degree of correlation across units. While the Moran's I calculated the degree of similarity across neighbor, Pesaran's test does not assume any structure. Both tests are distributed as a Normal under the null of cross sectional independence, if the cross sectional dimension is larger than the time series.

${ }^{13}$ These tests are based on the residual of the model and follow a chi-squared distribution with one degree of freedom.
} 
significance. ${ }^{14}$ This finding is also confirmed by the standard model selection criteria, like the AIC for example, which is lower for the SAR model compared to the SEM models. Similarly, the LR test rejects the null that SEM fits the data better than SAR at 10 percent confidence level.

Since the statistical tests find consistent evidence in favor of SAR, we use this specification in our further analysis. Before discussing the results, it is worth analyzing whether these are robust to the temporal variation in the coefficients. The literature has shown that the behavior of spreads could be subject to a structural break around 2000 (Gonzales Rosada and Levy Yeyati, 2008). We, therefore, estimate the SAR model on two sub-samples. In Column 4, we report the results for the 1995-2000 sample; in Column 5, we report the results for 2001-2010 sample. The evidence suggests that while the magnitude of spatial correlation has not changed, there seems to be a different role played by fundamentals and global factors in the first subsample. The spreads seem to be affected only by debt and growth, while global factors are insignificant. When we analyze the second subsample, we observe instead that all variables become significant and have the correct sign. However, since the second subsample includes the financial crisis of 2008-2009, we also re-estimate the model to make sure the results are not driven by this episode. In general, the crisis seems to have strengthened the impact of fundamentals on spreads but not those of global factors and the spatial autocorrelation. This result is consistent with the view that investors pay more attention to discriminate between good and bad borrowers as EM sovereigns are expanding as an asset class.

We now turn to the quantification of the results. In the SAR model, the coefficients do not have the same interpretation as in the standard FE model. While in the FE model the coefficients represent marginal effects, in the SAR model one could distinguish between "direct" effects and "total" effects that take into account also the feedback effect arising from the spatial autocorrelation. To understand why, if one takes the partial derivative of the spreads with respect to $x_{i t}$, the "direct" effect is given by $\beta_{k}$, while the "total" effect is given

by $(I-\rho W)^{-1} \beta_{k}$, where $\mathrm{W}=\left[\begin{array}{cccc}0 & w_{12} & \cdot & w_{1 N} \\ w_{21} & 0 & \cdot & w_{2 N} \\ \cdot & \cdot & \cdot & \cdot \\ w_{N 1} & w_{N 2} & \cdot & 0\end{array}\right]$ is the standardized weighting matrix. The

latter quantity embodies also "indirect" effects from changes in fundamentals in other countries. In fact, if $x_{j t}$ changes, this will affect directly $y_{j t}$ and indirectly $y_{i t}$ through the

\footnotetext{
${ }^{14}$ The corresponding statistics are 0.15 for the Robust LM error and 76.7 for the Robust LM lag test.
} 
spatial autocorrelation coefficient $\rho$ and the connectivity matrix $W$. Those two elements determine the spatial multiplier and the strength of spillovers.

Table 5 reports the results from this decomposition, which corresponds to the results in Column 5 of Table 4. The column labeled "direct effect” shows the effect from own changes in fundamentals once we account for the spatial multiplier. The indirect effect measures the impact on spread of changes in all other countries' fundamental $k$ that affects country $i$ through the spatial multiplier. Before commenting on the results for global factors, it is important to stress one difference from the literature. Since the factors are global, one should expect their effect to be equal in all countries. However, the SAR model allows the VIX to have the first direct impact which is equal in all countries, and then a second round effect which comes through spatial correlation. We in fact notice that the total impact of common factors is now similar to the values obtained in the literature. The elasticity (total impact) of the global factors is 0.67 , so that a 10 percent increase in the VIX leads to a 6.7 percent increase in spreads, which at the median of the sample (251 bps) correspond to $17 \mathrm{bps}$ approximately. When the expectation is for a 1 percent increase in the U.S. policy rate (around 100 bps at the sample median), the spreads will increase by 5 percent from their initial level (12 bps at the sample median). The results are in line with previous studies. Gonzales Rosada and Levy Yeyati (2008) find a significant role for factors related to risk. Hartelius et al. (2008) find a significant coefficient for present and future U.S. monetary policy, which they attribute to the more "forward looking” nature of the information embodied in the Fed Fund rate futures.

For the other variables, we notice that the omission of spillovers vastly underestimate the impact of changes in fundamentals. For example, the debt to GDP ratio is found to have a direct impact of approximately 0.75 bps for 1 percentage point of GDP increase, which is slightly lower than the value usually found in the literature (1-3 bps). ${ }^{15}$ However, once we take into account the indirect effects, the impact is about $1.2 \mathrm{bps}$. The effects are similar for the rest of the variables. The reserve to GDP ratio has a total impact of $1.6 \mathrm{bps}$ for a 1 percentage point increase. Inflation has a total impact of 2.3 bps for a 1 percentage point increase, while growth has an impact of 11 bps for a 1 percentage point increase. So, while fundamentals have a small direct impact, they trigger a higher response by having spatial spillovers on neighboring countries. In particular, if we look again at the result for growth, while the direct impact is of approximately 5 bps (as in the literature), it underestimates the true effect by almost 50 percent since it does not include the second round effect of spillovers from growth in neighboring countries.

In addition, our model sheds light on the factors that influenced the compression of the spreads between 2001 and 2008. Decomposition of the relative importance of domestic and

${ }^{15}$ See for example, Baldacci and Kumar (2010). 
global factors ${ }^{16}$ suggests that half of the observed variation (53 percent) is due to global factors, while the other half (47 percent) is due to domestic factors ${ }^{17}$. So while the continuous effort of countries toward improvement of their macroeconomic policy and a continuous integration of these economies in financial markets, which has occurred simultaneously across many countries, has attracted investors' interest generating positive spillovers, which also seem to indirectly affect neighboring countries, the "decoupling” from global shocks and indirectly from $\mathrm{AE}$ is not yet achieved. ${ }^{18}$

The results highlight an important policy implication for countries that continue their pace of integration to global financial markets. Given the existence of spillovers from global shocks and from other EM, it is important to reduce their vulnerabilities in good times, so that the impact of shocks is strongly diminished. To understand why, in Figure 2 we do the following thought experiment. We assume an increase in the debt to GDP ratio by 10 percentage points in all EM. The figure compares the projected increase in spreads according to the results of Table 5, Column 5. The resulting total effect is stronger for countries with a higher initial debt to GDP ratio. For countries with stronger fundamentals, the projected increase is moderate, less than $10 \mathrm{bps}$, while for other countries it can easily exceed $30 \mathrm{bps}$. This can have significant impact on the risk of refinancing, and it thus suggests the importance of improving the debt to GDP ratio in good times. ${ }^{19}$

\section{A. Different Weighting Matrices}

In the previous section we have performed the estimation assuming that distance proxies cross-country linkages. The approach was justified by the following two reasons: (i) there is substantial evidence that spillovers have regional components (Kaminsky and Reinhart, 2000), and (ii) econometric techniques require an exogenous structure of interaction, and geography clearly serves the purpose well.

The dynamics of economic interactions can be much more complex than a simple geographic structure. Therefore, it is important to assess to what extent results are sensitive to the adoption of the weighting structure, which is crucial for the estimation. The presumption is that spillovers might also be related to economic factors, like the strength of trade or financial relationships, or economic similarity across countries.

\footnotetext{
${ }^{16}$ The decomposition is performed by multiplying the coefficients of the model estimated in Column 5, Table 4 by the spatial multiplier $(I-\rho W)^{-1}$ and the mean value of the variables. The shares represent which portion of the variation of the model is explained by the two set of factors.

${ }^{17}$ Hartelius et al. (2008) obtain a similar result.

${ }^{18}$ See also Kose et al. (2008) for a similar point.

${ }^{19}$ On a similar point, see Gonzalez-Rosada and Levy-Yeyati (2008).
} 
In Table 6 we report the results assuming alternative weighting matrices. In Column 1 we use the square of the inverse of the distance, which further reduces the weight of more distant countries. In Column 2 we use correlation of output gaps across countries estimated using the Hodrick-Prescott filter as a measure of business cycle synchronization. In Columns 3-8 we report results using "economic distances". ${ }^{20}$ Since these weights are likely to be endogenous, we report the results assuming the structure as shown by the data available as of 2001 (beginning of sample) and as of 2009 (end of sample). In Columns 3-4 we use the relative trade intensity between countries. In Columns 5-6 we report the results by using relative financial flows. ${ }^{21}$ In Columns 7-8 we use relative investment grade status, where countries are connected if they share the same investment grade status. ${ }^{22} 23$

Using correlation of business cycles as a measure of cross-country linkages we find qualitatively similar results as when using geographic distances, with the spatial lag coefficient being relatively smaller. This reflects the fact that investors put larger weight on the geographical proximity of sovereigns relative to the business cycle synchronization. When using trade flows, the extent of spatial correlation seems to have increased over time (although a formal statistical test rejects the null of statistically different coefficients). When we use financial flows, we find instead that the spatial lag is significantly reduced compared to the model with geography as a distance matrix. While this could be a sign of insignificant financial linkages across EM, a caveat here is also related to the availability and quality of data. Data on bilateral portfolio holdings are available only for a subset of 20 countries, making a direct comparison of trade and financial linkages impossible. Beside data availability, also the extent of financial linkages across EM is still largely underreported, due to lack or, when available, poor quality of the data (IMF, 2011b). Finally, when we use economic similarity, we find that the effects are close to those obtained in the previous section, except that now, the coefficient on liquidity is insignificant.

\footnotetext{
${ }^{20}$ See Table 1 for a detailed description of data sources and construction of matrices.

${ }^{21}$ The data on bilateral portfolio holdings are not available for China, Cote d'Ivoire, Ecuador, and Peru.

${ }^{22}$ Data on rating status is not available for Cote d'Ivoire.

${ }^{23}$ There is no established way to test the relative statistical importance of the weighting matrices. The procedure of including all the weighting matrices at once and test the relative significance of the coefficients of the spatial lag is problematic for several reasons: data availability is different across weights; if one were to restrict the sample to be equal across all type of weights, it would probably run into the problem of information loss, rather than gaining information about the correct spatial structure of the data; since all the matrices provide an equally plausible structure in the data, one could encounter problems of multicollinearity, e.g., trade and distance being related.
} 


\section{ROBUSTNESS AND EXTENSIONS}

In this section we perform several robustness checks to confirm the validity of our results. We also augment the model with other explanatory variables which have been found to be significant in the literature. Table 7 summarizes the robustness results.

We start by showing that results are robust to the measurement of the dependent variables. Since fundamentals are semi-annual but spreads are available at high (daily) frequency, the issue is how to aggregate spreads to lower frequency. In Column 1 we replace the spread at the end of the month with the average spreads over the five months after the release of the forecast. The results show that the coefficients are robust to the way we measure spreads, thus that we are capturing the long-term relationship in the data ${ }^{24}$.

In Column 2, we address the issue of dynamics. Since spreads are financial variables, one can argue that there is a certain degree of dynamics which might be omitted from the estimation. Here, the problem is that there is no established technique to estimate a dynamic spatial model. We follow the advice of Kukenova and Monteiro (2008) and estimate the model using system GMM. The results show a higher degree of uncertainty in the estimates (standard errors are less precise than ML estimates), but the magnitude of the coefficients, including the spatial lag coefficient, is almost unchanged. ${ }^{25}$

In Column 3 we address the issue of omitted variables. Following the advice of LeSage and Pace (2009) we estimate the SDM model by introducing spatial lags of predictors. In this specification spreads might be affected not only by their own fundamentals, but also by the fundamentals of other countries. While this model has the advantage of being robust, it has a non-trivial interpretation. In fact, as in the SAR, the coefficients cannot be interpreted as marginal effects, but have to be analyzed as direct and indirect effects. ${ }^{26}$ What we find is that, the model stands well in terms of specification, as a Wald test rejects the null that the spatial lags of the regressors are all equal to zero. Nevertheless, when we estimate the direct and indirect effects, we find that most of the coefficients are insignificant, except for the debt to GDP ratio and the inflation rate. To understand the implication of this model, we use the following thought exercise-we assess the impact of an increase in debt in all the sample countries, including an indirect effect from the increase in debt in neighboring countries. Figure 3 shows that spreads will increase by a further 1 to 3 basis points for a 1 percent of GDP increase in the debt ratio. This is the spillovers of neighbors' fundamentals on domestic

\footnotetext{
${ }^{24}$ We have tried also with averages of spreads in the month and the quarter after release, but results do not change.

${ }^{25}$ Introducing dynamics allows the analysis of spatio-temporal impulse response of shocks to the regressors on the EMBI spreads. This is an interesting extension to the present work that we leave for future research.

${ }^{26}$ See Table 1 for how to interpret coefficients of the SDM.
} 
spreads. The effect is stronger in countries with higher levels of debt. ${ }^{27}$ We also run a twostep regression by regressing the EMBI spread on country specific fundamentals in the first step and using the residuals from this regression in the second step spatial regression to assess whether the residual variation can be ascribed to cross-country linkages. The results remain qualitatively unchanged, suggesting that even after controlling for regional fundamentals spatial spillovers persist.

In Column 4 we use other fiscal policy variables as regressors. First, in Column 4 we add to the specification the split of deficit between revenues and expenditures in the spirit of Akitobi and Stratmann (2008). We do not find significant coefficients on the two variables, and a test of equality accepts the null that the two coefficients are equal. In Column 5 we instead add to the model "governance" indicators, in particular, the political stability used in a paper on determinants of EM spreads by Baldacci et al. (2008). The results are in line with those obtained by the authors. Interestingly though, the results show also an extra benefit of good governance in our model: its indirect benefits on neighboring countries.

\section{CONCLUSIONS}

The economic importance of EM in the global economy and their increasing economic integration not only with AE but also with each other raises the important issue of the extent of interdependence among these markets. In this paper, we assess to what extent the EMBI spreads is affected by indirect spillovers due to financial and economic integration.

The results show that there are significant spillovers across EM. These can explain the strong convergence observed in the behavior of spreads during the last 10 years. Key channels for the transmission of shocks across EM are business cycle synchronization, trade links and geographical proximity, but financial links are also important. Nonetheless, EM financial markets are also increasingly integrated with advanced economies as about half of the variation in spreads is explained by financial and economic conditions in AE.

The paper provides several avenues for further research on the topic. First, a natural extension would be to assess the extent of spillovers in local currency bond markets, which are becoming an increasingly relevant source of financing in EM. Second, while the paper tries different possible structure of dependence in the weighting matrix, future work could use more micro data to describe countries' connections; for example, one could use information on the production chains to assess the possible effect of risks arising from production chains disruption. Finally, spatial econometrics techniques can be used to further shed light on the extent of contagion across countries.

\footnotetext{
${ }^{27}$ The model has other interesting aspects, like for example, the positive effect of neighbors' inflation on the spreads. This is another interesting extension that we leave for future research.
} 


\section{REFERENCES}

Acharya, V., Drechsler, I., and Schnabl, P. (2011) “A Pyrrhic Victory? Bank Bailouts and Sovereign Credit Risk”, NBER Working Paper No. 17136.

Akitoby, B., and Stratmann, T. (2008) “Fiscal Policy and Financial Markets”, The Economic Journal, 118, pp. 1971-1985.

Alper E., and Forni L. (2011) "Public Debt in Advanced Economies and its Spillover Effects on Long-Term Yields”, IMF Working Paper 11/210 (Washington: International Monetary Fund).

Balakrishnan, R., Danninger, E., Elekdag, S., and Tytell, I. (2009) “The Transmission of Financial Stress from Advanced to Emerging Economies,” IMF Working Paper 09/133 (Washington: International Monetary Fund).

Baldacci, E., and Kumar, M. (2010) "Fiscal Deficits, Public Debt, and Sovereign Bond Yields,” IMF Working Paper 10/184 (Washington: International Monetary Fund).

, Gupta, S., and Mati A. (2008) "Is it (Still) Mostly Fiscal? Determinants of Sovereign Spreads in Emerging Markets”, IMF Working Paper 08/259 (Washington: International Monetary Fund).

Bellas, D., Papaioannou, M., and Petrova, I. (2010) “Determinants of Emerging Market Sovereign Bond Spreads” in Sovereign Debt and the Financial Crisis, edited by C. A.P. Braga and C. Vincolette, pp.77- 101.

Caramazza, F., Ricci, L., and Salgado, R. (2000) "Trade and Financial Contagion in Currency Crises," IMF Working Paper 00/55 (Washington: International Monetary Fund).

Claessens, S., Tong, H., and Wei, S-J. (2011) "From the Financial Crisis to the Real Economy: Using Firm-Level Data to Identify Transmission Channels”, NBER Working Paper No. 17360.

Dornbusch, R., Park, Y., and Claessens, S. (2000) "Contagion: How it Spreads and How it Can be Stopped” World Bank Research Observer.

Dell'Erba S., and Sola S. (2011) "Expected Fiscal Policy and Interest Rates in Open Economy,” IHEID Working Papers 07-2011. 
Edwards, S. (1984) "LDC Foreign Borrowing and Default Risk: An Empirical Investigation, 1976-80”, American Economic Review, 74, pp. 726-34.

Eichengreen, B., and Mody, A. (1998) "What Explains Changing Spreads on Emerging Market Debt: Fundamentals or Market Sentiment”, National Bureau of Economic Research. Working Paper Series No. 6408.

, Rose, A., and Wyplosz, C. (1996) “Contagious Currency Crises: First Tests”, Scandinavian Journal of Economics, 98(4), pp. 463-84, December.

Elhorst, J. (2010) Spatial Panel Data Models. In Fischer M., Getis A (Eds.) Handbook of Applied Spatial Analysis, pp. 377-407.

Forbes, K., and Rigobon, R. (2002) “No Contagion, Only Interdependence: Measuring Stock Market Comovements”, Journal of Finance, 57(5), pp. 2223-261.

Gonzalez-Rosada, M., and Levy-Yeyati, E. (2008) “Global Factors and Emerging Markets Spreads”, The Economic Journal, 118, pp. 1917-1936.

Glick, R., and Rose, A. (1999) "Contagion and Trade: Why Are Currency Crises Regional?”,Journal of International Money and Finance, 18(4), pages 603-617, August.

Hartelius, K., Kashiwase, K., and Kodres, L. (2008) “Emerging Market Spread Compression: Is It Real or is it Liquidity?”, IMF Working Paper 08/10 (Washington: International Monetary Fund).

Hernández, L., and Valdés, R. (2001) "What Drives Contagion: Trade, Neighborhood, or Financial Links?” IMF Working Paper 01/29 (Washington: International Monetary Fund).

IMF (2011a) “Changing Patterns of Global Trade”, IMF Policy Paper, June (Washington: International Monetary Fund).

(2011b) "Mapping Cross-Border Financial Linkages: A Supporting Case for Global Financial Safety Nets” IMF Policy Paper, June (Washington: International Monetary Fund).

Kelejian H., Tavlas G., and Hondroyiannis G. (2006) “A Spatial Modeling Approach to Contagion Among Emerging Economies,” Open Economies Review, 17(4), pages 423-441, December. 
Kaminsky, G., and Reinhart, C. (2000) “On Crises, Contagion, and Confusion,” Journal of International Economics, Elsevier, 51(1), pages 145-168, June.

Laubach, T. (2009) "New Evidence on the Interest Rate Effects of Budget Deficits and Debt,” Journal of European Economic Association, 7, pp. 858-85.

Manasse, P., Roubini, N., and Schimmelpfennig A. (2003) “'Predicting Sovereign Debt Crises,” IMF Working Paper 03/221 (Washington: International Monetary Fund).

McGuire, P., and Schrijvers, M. (2003) "Common Factors in Emerging Market Spreads” BIS Quarterly Review, December.

Min, H. (1998) "Determinants of Emerging Market Bond Spreads. Do Economic Fundamentals Matter?” World Bank Policy Research Working Paper, 1899.

Novo, A. (2003) "Contagious Currency Crisis: A Spatial Probit Approach,” Working Papers w200305, Banco de Portugal, Economics and Research Department.

Pesaran, M., and Pick, A. (2007) "Econometric Issues in the Analysis of Contagion”, Journal of Economic Dynamics and Control, Elsevier, 31(4), pp. 1245-1277.

Sbracia M., and Zaghini, A. (2003) "The Role of the Banking System in the International Transmission of Shocks”, The World Economy, Wiley Blackwell, 26(5), pp. 727-754.

Sgherri S., and Zoli, E. (2009) “Euro Area Sovereign Risk During the Crisis,” IMF Working Paper 09/222 (Washington: International Monetary Fund).

Tong, H., and Wei, S-J. (2011) "The Composition Matters: Capital Inflows and Liquidity Crunch During a Global Economic Crisis”, Review of Financial Studies, 24(6), pp. 2023-52.

Uribe, M., and Zue, V. (2006) "Country Spreads and Emerging Countries: Who Drives Whom?” Journal of International Economics, 69, pp.6-36.

Van Rijckeghem, C., and Weder, B. (2001) "Sources of Contagion: Is it Finance or Trade?”, Journal of International Economics, Elsevier, 54(2), pp. 293-308. 
Figure 1. Sovereign Spreads in Emerging Markets (in basis points)

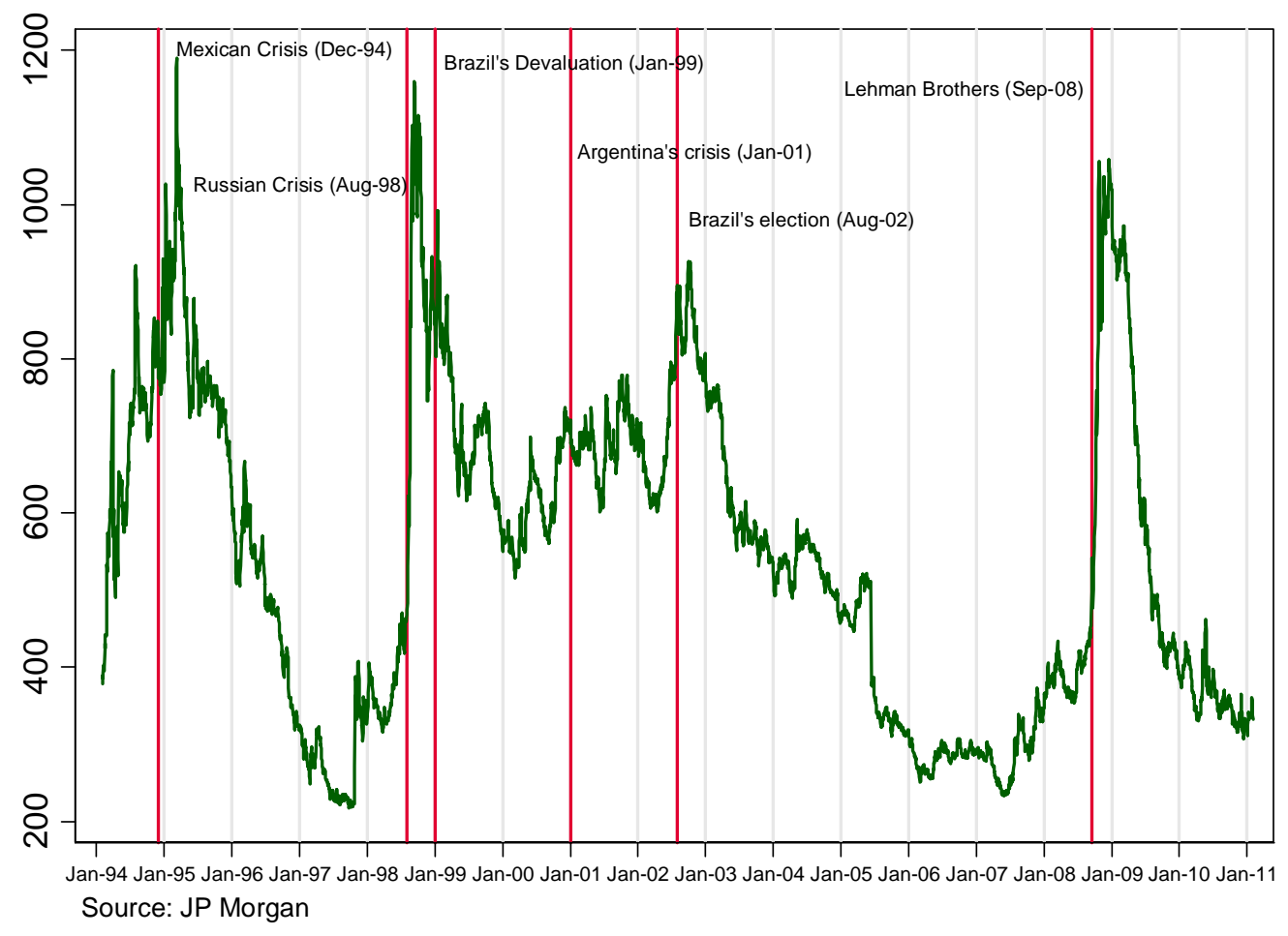


Figure 2. SAR: The Impact of a 1 ppt Increase in External Debt to GDP Ratio

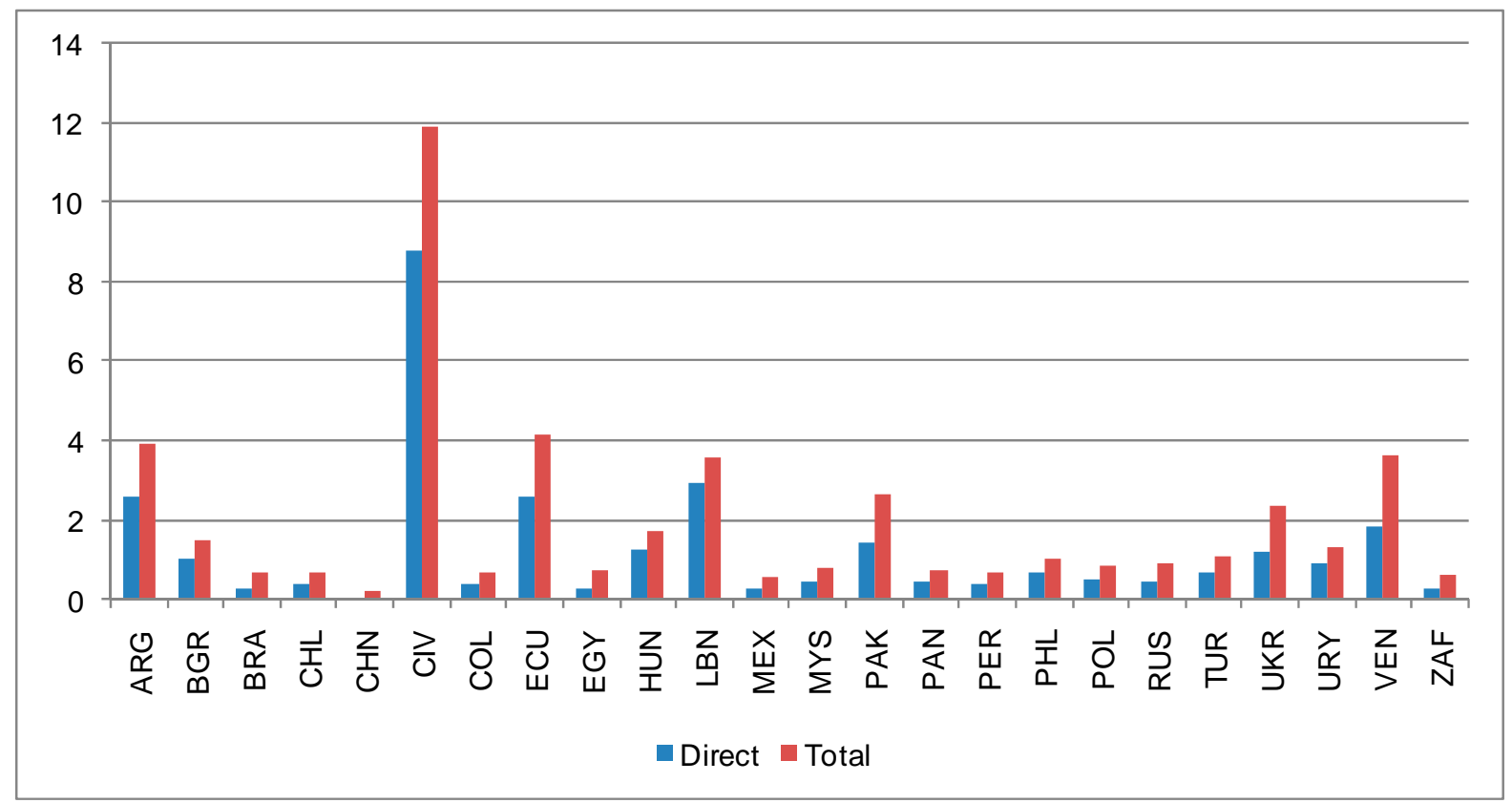

Note:

The direct effect corresponds to the elasticity $\beta_{\text {debt }} * 0.01 * E(D e b t)_{i}$ which is multiplied by the average level of the EMBI spreads as of 2010 . The total effect corresponds to the elasticity $\beta_{\text {debt }} * 0.01 *(I-\rho W)^{-1} E(D e b t)$, which is then multiplied by the average level of the EMBI spreads as of 2010. 
Figure 3. SDM: The Impact of a 1 ppt Increase in External Debt to GDP Ratio

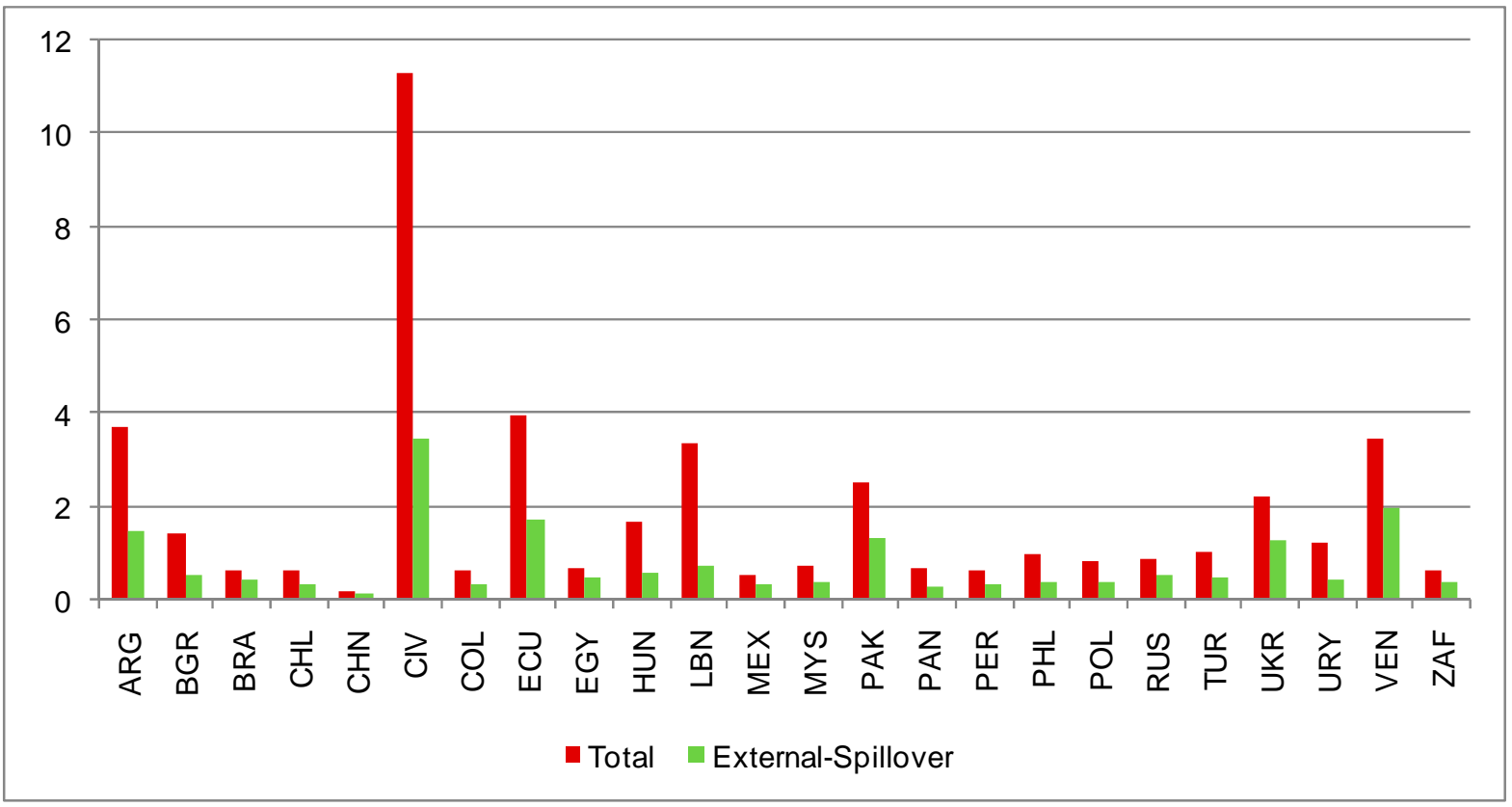

Note:

The total effect corresponds to the elasticity $\beta_{\text {debt }} * 0.01 *(I-\rho W)^{-1} E(D e b t)_{t}$ which is multiplied by the average level of the EMBI spreads as of 2010. The external-spillover effect corresponds to the elasticity $\delta_{d e b t} * 0.01 *(I-\rho W)^{-1} E(D e b t)_{t}$ which is then multiplied by the average level of the EMBI spreads as of 2010. 
Table 1. Description of Variables and their Sources

\begin{tabular}{|c|c|c|}
\hline Variable & Description & Source \\
\hline \multicolumn{3}{|l|}{ Financial variables } \\
\hline $\mathrm{EMBI}$ & JP Morgan E MBI global index blended spread & Datastream \\
\hline FFF & Fed Funds future rate & Datastream \\
\hline VIX & CBOE Volatility Index & Datastream \\
\hline \multicolumn{3}{|l|}{ Real Time data } \\
\hline Ext.Debt/GDP t+1 & One year ahead Total External Debt over GDP & WE O \\
\hline $\mathrm{Res} / \mathrm{G} D P \mathrm{t}+1$ & One year ahead External Reserves of GDP & WE O \\
\hline G rowth $\mathrm{t}+1$ & One year ahead real growth rate & WEO \\
\hline Inflation $\mathrm{t}+1$ & One year ahead CPI inflation rate & WE O \\
\hline Weighting matrix & Description & Source \\
\hline Distance & Inverse of the distance based on latitude and longitude & CEPII \\
\hline Trade linkages & S um of bilateral export and import, over GDP & DOTS \\
\hline Financial linkages & $\begin{array}{l}\text { Share of bilateral total portfolio investment over total } \\
\text { portfolio investment }\end{array}$ & CPIS \\
\hline Sovereign rating & $\begin{array}{l}\text { Dummy equal to } 1 \text { if two countries share the same } \\
\text { investment grade status }\end{array}$ & Moody's \\
\hline
\end{tabular}

Note:

Countries included in the analysis are: Argentina (ARG), Bulgaria (BGR), Brazil (BRA), Chile $(\mathrm{CHL})$, China (CHN), Côte d'Ivoire (CIV), Colombia (COL), Ecuador (ECU), Egypt (EGY), Hungary (HUN), Lebanon (LBN), Mexico (MEX), Malaysia (MYS), Pakistan (PAK), Panama (PAN), Peru (PER), Philippines (PHL), Poland (POL), Russia (RUS), Turkey (TUR), Ukraine (UKR), Uruguay (URY), Venezuela (VEN), and South Africa (ZAF). 
Table 2. Summary Statistics

\begin{tabular}{lrrrrrr}
\hline \hline \multicolumn{1}{c}{ Variable } & Obs. & \multicolumn{1}{c}{ Mean } & \multicolumn{1}{c}{ Median } & \multicolumn{1}{c}{ Std Dev } & \multicolumn{1}{c}{ Min } & Max \\
\hline \hline & & & & & & \\
EMBI & 675 & 530.64 & 315.13 & 658.26 & 19.45 & 4993.46 \\
VIX & 850 & 22.05 & 19.78 & 9.75 & 11.31 & 61.18 \\
Future Fed Fund & 850 & 2.84 & 1.86 & 2.09 & 0.11 & 6.50 \\
Debt/GDP & 850 & 0.48 & 0.41 & 0.31 & 0.00 & 2.11 \\
Res/GDP & 796 & 0.17 & 0.13 & 0.13 & 0.02 & 0.95 \\
Inflation & 850 & 0.09 & 0.05 & 0.10 & 0.01 & 1.00 \\
Growth & 850 & 0.04 & 0.04 & 0.02 & -0.06 & 0.13 \\
\hline
\end{tabular}


Table 3. Tests of Cross Sectional Dependence

\begin{tabular}{lrrrr}
\hline \hline & Moran's I & \multicolumn{1}{l}{ p-value } & CD-test & p-value \\
\hline \hline & & & & \\
EMBI & 12.62 & 0.0000 & 65.35 & 0.0000 \\
Debt/GDP & 1.31 & 0.0950 & 48.16 & 0.0000 \\
Res/GDP & 6.28 & 0.0000 & 63.66 & 0.0000 \\
Growth & 7.47 & 0.0000 & 47.67 & 0.0000 \\
Inflation & 8.23 & 0.0000 & 51.87 & 0.0000 \\
Residual & 27.82 & 0.0000 & 11.47 & 0.0000 \\
\hline
\end{tabular}

Note: The null hypothesis is that the units are cross-sectionally independent. 
Table 4. Estimation Results: Fixed-Effects, Spatial Error, and Spatial Lag Models

\begin{tabular}{|c|c|c|c|c|c|c|}
\hline & (1) & (2) & (3) & (4) & (5) & (6) \\
\hline \multirow[t]{2}{*}{ VARIABLES } & $\mathrm{FE}$ & SEM & SAR & SAR & SAR & SAR \\
\hline & & & & $1994-2000$ & $2001-2010$ & 2001-2007 \\
\hline \multirow[t]{2}{*}{ Log Vix } & $0.7197^{* * *}$ & $0.7112^{* * *}$ & $0.4000 * * *$ & -0.0328 & $0.3931 * * *$ & $0.3188^{* * *}$ \\
\hline & $(0.082)$ & $(0.073)$ & $(0.057)$ & $(0.092)$ & $(0.061)$ & $(0.091)$ \\
\hline \multirow[t]{2}{*}{ FFF } & $0.0618^{* *}$ & $0.0589 * * *$ & 0.0178 & $-0.0952^{* *}$ & $0.0303^{*}$ & $0.0425 *$ \\
\hline & $(0.024)$ & $(0.022)$ & $(0.015)$ & $(0.037)$ & $(0.016)$ & $(0.016)$ \\
\hline \multirow[t]{2}{*}{ Ext.Debt/GDP t+1 } & $0.7913^{* * *}$ & $0.7576^{* * *}$ & $0.7416 * * *$ & $0.6098 * *$ & $0.6568 * * *$ & $0.3770 * * *$ \\
\hline & $(0.267)$ & $(0.110)$ & (0.105) & $(0.237)$ & (0.117) & (0.107) \\
\hline \multirow[t]{2}{*}{ Res/GDP $t+1$} & $-1.2725 *$ & $-1.1301 * * *$ & $-1.1369 * * *$ & -0.1960 & $-0.9021^{* * *}$ & $-0.6020^{* * *}$ \\
\hline & $(0.638)$ & $(0.253)$ & $(0.242)$ & $(0.265)$ & $(0.286)$ & $(0.283)$ \\
\hline \multirow[t]{2}{*}{ Growth $\mathrm{t}+1$} & $-9.3787 * * *$ & $-9.9414 * * *$ & $-9.2000 * * *$ & $-11.4962 * * *$ & $-6.6376 * * *$ & $-5.1363 * * *$ \\
\hline & (2.799) & (1.885) & (1.711) & (1.923) & (1.621) & (1.762) \\
\hline \multirow[t]{2}{*}{ Inflation $\mathrm{t}+1$} & 1.1966 & $0.8222^{* *}$ & $0.9894^{* * *}$ & 0.1113 & $1.3223^{* *}$ & $0.5185^{* *}$ \\
\hline & $(0.833)$ & $(0.366)$ & (0.362) & $(0.329)$ & $(0.595)$ & $(0.496)$ \\
\hline \multirow[t]{2}{*}{$\mathrm{W}^{*} \varepsilon$} & & $0.4136 * * *$ & & & & \\
\hline & & $(0.058)$ & & & & \\
\hline \multirow[t]{2}{*}{ W*Log Embi } & & & $0.3918^{* * *}$ & $0.4732^{* * *}$ & $0.4205^{* * *}$ & $0.5049 * * *$ \\
\hline & & & $(0.049)$ & $(0.075)$ & $(0.056)$ & $(0.075)$ \\
\hline Observations & 650 & 662 & 662 & 206 & 456 & 312 \\
\hline R2 & 0.440 & 0.518 & 0.567 & 0.458 & 0.645 & 0.624 \\
\hline AIC & 1.205 & 1.115 & 1.108 & 0.410 & 0.800 & 0.590 \\
\hline LL & -385.7 & -367.1 & -364.7 & -40.23 & -180.4 & -85.16 \\
\hline LR & & 37.21 & 4.732 & & & \\
\hline P-value & & 0.0000 & 0.0939 & & & \\
\hline
\end{tabular}

Note:

The dependent variable is the log of the EMBI spread observed at the end of the month of the release of the forecast, April and October.

FE $=$ Fixed Effect

SEM = Spatial Error Model

SAR = Spatial Autoregressive model; VIX is the volatility index, FFF is the Fed Funds future rate.

$\mathrm{W}=$ Inverse of the distance

$\mathrm{LL}=$ Log-Likelihood, while

$\mathrm{LR}=$ Likelihood Ratio statistics, which is distributed as a Chi-Square.

Robust standard errors are in parenthesis. 
Table 5. Decomposition of the Total Impact into Direct and Indirect Effects

\begin{tabular}{lrrr}
\hline \hline & \multicolumn{1}{c}{$(1)$} & \multicolumn{1}{c}{$(2)$} & \multicolumn{1}{c}{$(3)$} \\
VARIABLES & \multicolumn{1}{c}{ Direct } & \multicolumn{1}{c}{ Indirect } & \multicolumn{1}{c}{ Total } \\
\hline \hline Log Vix & $0.4053^{* * *}$ & $0.2697^{* * *}$ & $0.6751^{* * *}$ \\
& $(0.066)$ & $(0.048)$ & $(0.076)$ \\
FFF & $0.0308^{* * *}$ & 0.0202 & $0.0510^{* * *}$ \\
& $(0.015)$ & $(0.010)$ & $(0.024)$ \\
Ext.Debt/GDP t+1 & $0.6794^{* * *}$ & $0.4657^{* * *}$ & $1.1452^{* * *}$ \\
& $(0.090)$ & $(0.133)$ & $(0.189)$ \\
Res/GDP t+1 & $-0.971^{* * *}$ & $-0.668^{* * *}$ & $-1.639^{* * *}$ \\
& $(0.249)$ & $(0.253)$ & $(0.463)$ \\
Inflation $\mathrm{t}+1$ & $1.3675^{* * *}$ & $0.9382^{* * *}$ & $2.3058^{* * *}$ \\
& $(0.509)$ & $(0.433)$ & $(0.894)$ \\
Growth $\mathrm{t}+1$ & $-6.844^{* * *}$ & $-4.677^{* * *}$ & $-11.52^{* * *}$ \\
& $(1.371)$ & $(1.483)$ & $(2.515)$ \\
\hline
\end{tabular}

Note:

The calculation are based on the following $\left(I^{*} \beta_{k}\right) *(I-\rho W)^{-1}$ where each of the coefficients $k$ in Table 3, Column 5 , is multiplied against the spatial multiplier $(I-\rho W)^{-1}$. The column "direct" corresponds to the average value of the diagonal of the resulting matrix, while the column "indirect" are the average of the row-sums of the off-diagonal elements. Standard errors are based on 10.000 Monte Carlo simulations. 
Table 6. Estimation Results: Spatial Lag Model with Alternative Weighting Matrices

\begin{tabular}{|c|c|c|c|c|c|c|c|c|}
\hline VARIABLES & $\begin{array}{c}(1) \\
\text { Distance } \\
\text { squared }\end{array}$ & $\begin{array}{c}(2) \\
\text { Business } \\
\text { cycle }\end{array}$ & $\begin{array}{c}(3) \\
\text { Trade linkages - } \\
2001\end{array}$ & $\begin{array}{c}(4) \\
\text { Trade linkages- } \\
2010\end{array}$ & $\begin{array}{c}\text { (5) } \\
\text { Financial } \\
\text { linkages }-2001\end{array}$ & $\begin{array}{c}(6) \\
\text { Financial } \\
\text { linkages-2009 }\end{array}$ & $\begin{array}{c}(7) \\
\text { Sovereign } \\
\text { rating-2001 }\end{array}$ & $\begin{array}{c}\text { (8) } \\
\text { S overeign } \\
\text { rating-2010 }\end{array}$ \\
\hline Log Vix & $\begin{array}{r}0.3168 * * * \\
(0.068)\end{array}$ & $\begin{array}{r}0.5407^{* * *} \\
(0.073)\end{array}$ & $\begin{array}{r}0.4609 * * * \\
(0.063)\end{array}$ & $\begin{array}{r}0.3472^{* * *} \\
(0.055)\end{array}$ & $\begin{array}{r}0.6430 * * * \\
(0.059)\end{array}$ & $\begin{array}{r}0.6537^{* * *} \\
(0.061)\end{array}$ & $\begin{array}{r}0.3848^{* * *} \\
(0.074)\end{array}$ & $\begin{array}{r}0.4121 \text { *** } \\
(0.072)\end{array}$ \\
\hline FFF & $\begin{array}{r}0.0195 \\
(0.014)\end{array}$ & $\begin{array}{r}0.0537^{* * *} \\
(0.017)\end{array}$ & $\begin{array}{r}0.0293 \\
(0.015)\end{array}$ & $\begin{array}{r}0.0496^{* * *} \\
(0.016)\end{array}$ & $\begin{array}{r}0.0400^{* * *} \\
(0.016)\end{array}$ & $\begin{array}{r}0.0495^{* * *} \\
(0.016)\end{array}$ & $\begin{array}{r}-0.001 \\
(0.014)\end{array}$ & $\begin{array}{r}-0.003 \\
(0.014)\end{array}$ \\
\hline Ext.Debt/G DP $t+1$ & $\begin{array}{r}0.6510^{* * *} \\
(0.084)\end{array}$ & $\begin{array}{r}0.7285^{* * *} \\
(0.127)\end{array}$ & $\begin{array}{r}0.6774^{* * *} \\
(0.089)\end{array}$ & $\begin{array}{r}0.6946^{* * *} \\
(0.088)\end{array}$ & $\begin{array}{r}0.9106^{* * *} \\
(0.098)\end{array}$ & $\begin{array}{r}0.8992^{* * *} \\
(0.099)\end{array}$ & $\begin{array}{r}0.8548^{* * *} \\
(0.092)\end{array}$ & $\begin{array}{r}0.8314^{* * *} \\
(0.092)\end{array}$ \\
\hline Res/GDP t+1 & $\begin{array}{r}-0.889^{* * *} \\
(0.234)\end{array}$ & $\begin{array}{r}-0.9783^{* * *} \\
(0.320)\end{array}$ & $\begin{array}{r}-0.945^{* * *} \\
(0.248)\end{array}$ & $\begin{array}{r}-0.889^{* * *} \\
(0.246)\end{array}$ & $\begin{array}{r}-1.477^{* * *} \\
(0.283)\end{array}$ & $\begin{array}{r}-1.639 * * * \\
(0.285)\end{array}$ & $\begin{array}{r}-0.997^{* * *} \\
(0.254)\end{array}$ & $\begin{array}{r}-1.026^{* * *} \\
(0.255)\end{array}$ \\
\hline Inflation $\mathrm{t}+1$ & $\begin{array}{r}1.4587^{* * *} \\
(0.473)\end{array}$ & $\begin{array}{r}1.6191^{* * *} \\
(0.615)\end{array}$ & $\begin{array}{r}1.3689^{* * *} \\
(0.500)\end{array}$ & $\begin{array}{r}1.3380^{* * *} \\
(0.494)\end{array}$ & $\begin{array}{r}1.4595^{* * *} \\
(0.509)\end{array}$ & $\begin{array}{r}1.0700^{* * *} \\
(0.514)\end{array}$ & $\begin{array}{r}1.5075^{* * *} \\
(0.494)\end{array}$ & $\begin{array}{r}1.4446^{* * *} \\
(0.494)\end{array}$ \\
\hline G rowth $\mathrm{t}+1$ & $\begin{array}{r}-6.618^{* * *} \\
(1.293)\end{array}$ & $\begin{array}{r}-6.9970 * * * \\
(1.632)\end{array}$ & $\begin{array}{r}-6.976^{* * *} \\
(1.348)\end{array}$ & $\begin{array}{r}-7.239 * * * \\
(1.328)\end{array}$ & $\begin{array}{r}-5.124^{* * *} \\
(1.436)\end{array}$ & $\begin{array}{r}-4.933^{* * *} \\
(1.450)\end{array}$ & $\begin{array}{r}-6.328^{* * *} \\
(1.357)\end{array}$ & $\begin{array}{r}-6.123^{* * *} \\
(1.350)\end{array}$ \\
\hline W*Log E mbi & $\begin{array}{r}0.5039^{* * *} \\
(0.069)\end{array}$ & $\begin{array}{r}0.2318^{* * *} \\
(0.072)\end{array}$ & $\begin{array}{r}0.3389^{* * *} \\
(0.058)\end{array}$ & $\begin{array}{r}0.4359^{* * *} \\
(0.051)\end{array}$ & $\begin{array}{r}0.2409^{* * *} \\
(0.046)\end{array}$ & $\begin{array}{r}0.2049 * * * \\
(0.048)\end{array}$ & $\begin{array}{r}0.4919^{* * *} \\
(0.066)\end{array}$ & $\begin{array}{r}0.4879^{* * *} \\
(0.064)\end{array}$ \\
\hline Observations & 456 & 456 & 456 & 456 & 380 & 380 & 437 & 437 \\
\hline R 2 & 0.602 & 0.613 & 0.613 & 0.604 & 0.652 & 0.649 & 0.628 & 0.634 \\
\hline AIC & 0.820 & 0.860 & 0.829 & 0.809 & 0.779 & 0.790 & 0.739 & 0.737 \\
\hline $\mathrm{LL}$ & -180.889 & -194.2 & -182.923 & -178.408 & -143.998 & -146.044 & -157.448 & -157.023 \\
\hline
\end{tabular}

Note:

The dependent variable is the log of the EMBI spreads observed at the end of the month of the release of the forecast, April and October.

Distance squared $=\quad$ inverse of the distance squared.

Business cycle $=\quad$ correlation matrix of output gaps estimated using the Hodrick-Prescott filter.

Trade linkages $2001=\quad$ the bilateral export plus import over GDP as of 2001.

Trade linkages $2010=$ the bilateral export plus import over GDP as of 2010.

Financial linkages $2001=$ the bilateral share of CPIS total portfolio investment over total investments as of 2001.

Financial linkages $2009=$ the bilateral share of CPIS total portfolio investment over total investments as of 2009.

Sovereign rating $2001=$ the matrix takes the value $=1$ if two countries share the same investment status as of 2001.

Sovereign rating $2010=$ the matrix takes the value $=1$ if two countries share the same investment status as of 2010.

$\mathrm{LL}=\quad$ Log-Likelihood.

Robust standard errors are in parentheses. 


\section{Table 7. Robustness Checks}

\begin{tabular}{|c|c|c|c|c|c|}
\hline YARIARIFS & $\begin{array}{c}(1) \\
(1)\end{array}$ & (2) & (3) & (4) & (5) \\
\hline VARIABLES & ASAR & $A B$ & & & \\
\hline \multirow[t]{2}{*}{ Log VIX } & $0.3850 * * *$ & 0.2369 & $0.4265 * * *$ & $0.3934 * * *$ & $0.4190 * * *$ \\
\hline & $(0.063)$ & $(0.213)$ & $(0.056)$ & $(0.061)$ & (0.097) \\
\hline \multirow[t]{2}{*}{ FFF } & $0.0451 * * *$ & -0.0134 & $0.0313 * * *$ & $0.0269 *$ & 0.0307 \\
\hline & $(0.017)$ & $(0.039)$ & (0.015) & (0.016) & $(0.021)$ \\
\hline \multirow[t]{2}{*}{ Ext.Debt/GDP t+1 } & $0.6606 * * *$ & 1.0581 & $0.6450 * * *$ & $0.6482 * * *$ & $0.7311^{* * *}$ \\
\hline & $(0.105)$ & $(0.805)$ & (0.124) & (0.120) & (0.119) \\
\hline \multirow[t]{2}{*}{$\operatorname{Res} / G D P t+1$} & $-0.8130 * * *$ & -1.9509 & $-0.7961 * *$ & $-0.8474 * * *$ & $-1.235 * * *$ \\
\hline & $(0.266)$ & $(1.297)$ & $(0.321)$ & $(0.283)$ & $(0.332)$ \\
\hline \multirow[t]{2}{*}{ Growth $\mathrm{t}+1$} & $-6.1273 * * *$ & -4.3257 & $-7.6469 * * *$ & $-6.4149 * * *$ & $-7.522 * * *$ \\
\hline & $(1.575)$ & (3.541) & (2.056) & (1.624) & (1.961) \\
\hline \multirow[t]{2}{*}{ Inflation $\mathrm{t}+1$} & $1.1927^{*}$ & $3.4002 *$ & $1.2646^{*}$ & $1.1233^{*}$ & $1.5686^{* * *}$ \\
\hline & $(0.672)$ & (1.763) & $(0.702)$ & $(0.581)$ & (0.708) \\
\hline \multirow[t]{2}{*}{$W^{*}$ Log Embi } & $0.4317 * * *$ & $0.4233^{*}$ & $0.3651 * * *$ & $0.4234 * * *$ & \\
\hline & $(0.056)$ & $(0.255)$ & (0.017) & (0.056) & \\
\hline \multirow[t]{2}{*}{ Rev/GDP } & & & & -1.4178 & \\
\hline & & & & $(0.976)$ & \\
\hline \multirow[t]{2}{*}{ Exp/GDP } & & & & 1.2073 & \\
\hline & & & & $(1.015)$ & \\
\hline \multirow[t]{2}{*}{ Log Embi Lag } & & 0.1838 & & & \\
\hline & & $(0.117)$ & & & \\
\hline \multirow[t]{2}{*}{$W^{*}$ debt } & & & $0.7525 * * *$ & & \\
\hline & & & $(0.235)$ & & \\
\hline \multirow[t]{2}{*}{ W*Res } & & & -1.2808 & & \\
\hline & & & $(0.847)$ & & \\
\hline \multirow[t]{2}{*}{$W^{*} \operatorname{Inf}$} & & & 2.4096 & & \\
\hline & & & $(1.628)$ & & \\
\hline \multirow[t]{2}{*}{$W^{*}$ Growth } & & & $4.5362^{*}$ & & \\
\hline & & & $(2.737)$ & & \\
\hline \multirow[t]{2}{*}{ Political Stability } & & & & & $-0.265^{* * *}$ \\
\hline & & & & & $(0.076)$ \\
\hline Observations & 456 & 455 & 456 & 456 & 240 \\
\hline $\mathrm{R} 2$ & 0.597 & 0.602 & 0.602 & 0.602 & 0.645 \\
\hline AIC & 0.582 & & 0.831 & 0.795 & 0.602 \\
\hline LL & -130.8 & & -187.5 & -179.2 & -66.2 \\
\hline T-test Rev=Exp & & & & 1.933 & \\
\hline P-Val & & & & 0.164 & \\
\hline Number of id & & 24 & & & \\
\hline \# Instr. & & 36 & & & \\
\hline $\operatorname{AR}(2)$ & & 0.550 & & & \\
\hline Hansen-J & & 19.78 & & & \\
\hline Wald-Test & & & 23.32 & & \\
\hline P-value & & & 0.0001 & & \\
\hline
\end{tabular}

Note:

ASAR = The dependent variable is the average of the log of the EMBI spreads observed in the five months after the release of the forecast, April and October.

$A B=$ System GMM estimation, where the dependent variable is the same as in the column ASAR.

$\mathrm{SDM}=$ Spatial Durbin model, with $\mathrm{W}=$ =inverse distance. 